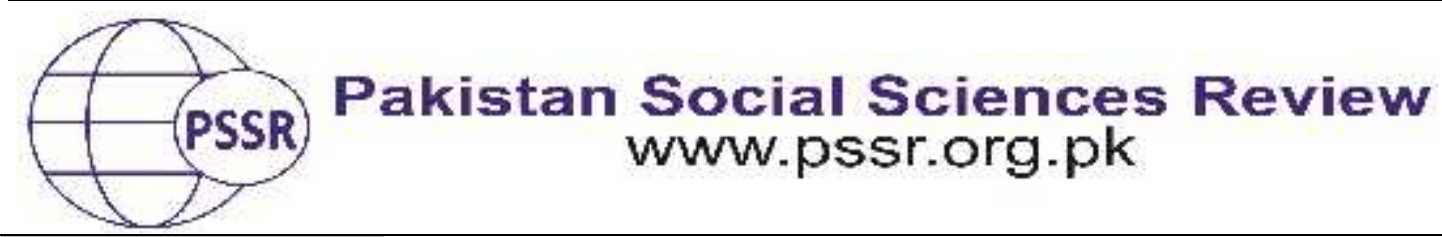

RESEARCH PAPER

\title{
Legal Framework of Foreign Investment in Pakistan: An Appraisal of Protectionist Approach
}

\author{
Ali Nawaz Khan ${ }^{1}$ Dr. Hafiz Aziz ur Rehman ${ }^{2}$
}

1. Assistant Professor, University Law College, University of the Punjab, Lahore, Punjab, Pakistan

2. Assistant Professor: Department of Law, International Islamic University, Islamabad, Pakistan

\begin{tabular}{|c|c|}
\hline PAP & BSTRACT \\
\hline $\begin{array}{l}\text { Received: } \\
\text { October } 18,2020 \\
\text { Accepted: } \\
\text { December } 05,2020 \\
\text { Online: } \\
\text { December } 31,2020\end{array}$ & $\begin{array}{l}\text { Since its creation, Pakistan supported free market economic } \\
\text { regime. The policy framework, domestic and international } \\
\text { instrumentality of the country has subscribed a protectionist } \\
\text { approach for foreign investment. The successive governments of } \\
\text { the state participated to adopt number of multilateral and }\end{array}$ \\
\hline $\begin{array}{l}\text { Keywords: } \\
\text { Foreign } \\
\text { Investment, Legal } \\
\text { Framework, } \\
\text { Protectionist } \\
\text { Approach } \\
\end{array}$ & $\begin{array}{l}\text { bilateral instruments of international obligations for the } \\
\text { protection of foreign investment in the country. State organs } \\
\text { have acknowledged pursuance of protectionist approach for } \\
\text { foreign investment in Pakistan. Thus, a pro-investor system of } \\
\text { foreign investment has been emerged. This paper examined }\end{array}$ \\
\hline $\begin{array}{l}\text { Corresponding } \\
\text { Author } \\
\text { alinawaz.law@p } \\
\text { u.edu.pk }\end{array}$ & $\begin{array}{l}\text { contemporary legal framework of foreign investment protection } \\
\text { of Pakistan and investigated how inherent protectionist } \\
\text { approach of Investor state dispute settlement (ISDS) has } \\
\text { postulated challenges for national interest of the country. }\end{array}$ \\
\hline
\end{tabular}

\section{Introduction}

Pakistan, since its creation in 1947, participated for free market economic model in pursuit of economic stability and related nation building objectives. The successive governments in Pakistan have owed its commitments to international institutions to the effect of promoting and protecting foreign investments in the country. This paper discusses that Pakistan has adopted regulatory framework in conformity with the new economic order initiated by international organizations i.e. UNO, World Bank. The dependency of national economic goals on private participations persuaded the governments in Pakistan to adopt a facilitative rather pro-investor protectionist regulatory framework for trade and foreign investments. Pakistan ratified number of international agreements to facilitate international trade and foreign investment in the country. 
An affirmative protectionist approach was also incorporated in the policy and statutory in Pakistan. Constitutional and legislative measures have extended its support for the development of liberalized economic regime in the country. The economic plans and future economic strategies have been formulated to facilitate private sector from inside and outside the country for investment. State organs have reinforced policies of promotion and protection of foreign investment. Pakistan has developed a facilitative legal framework for the foreign investments.

In pursuance to the protectionist approach for foreign investment, Pakistan has owed its obligations for standard of treatment and to provide an impartial investor state disputes settlement (ISDS). Pakistan has executed more than half century of investment treaties with more than fifty countries for the promotion and protection of foreign investment. State has also ratified ICSID Convention, 1965 to accept transnational jurisdiction for investor state dispute settlement mechanism as an impartial and independent mechanism. International instruments including bilateral and multilateral investment treaties have been major source of conferment of ICSID jurisdiction. Proliferation of investment treaties signed in the last decade of $20^{\text {th }}$ century, after Cold War, has introduced ICSID mechanism for the settlement of investment disputes. Major portion of instruments of foreign investment protection in Pakistan were also signed during the same decade.

The paper concluded that contemporary legal framework of foreign investment in Pakistan has engendered vulnerability challenges for the national interest of the state. The redefining approach of transnational forum of ISDS has compromise sovereign interests of the state. A rationale approach to balance the interests of the foreign investors and national interests of the host state could create equilibrium between contesting rights.

\section{National Framework of Foreign Investment Protection}

Pakistan is governed by a written constitution of parliamentary form of government. The Constitution of Islamic Republic of Pakistan, 1973 provided a structure of trichotomy of powers among three organs of the state: Legislature, Executive and judiciary. The Constitution vests executive and legislative powers with Federal Government and Parliament respectively. Parliament has the authority to make laws and superior judiciary in Pakistan has been vested with power to interpret the legislations and executive put the laws into execution (Constitution of Pakistan, 1973). Executive has the authority to take measures not prohibited under the Constitution to implement policies of political government. Governments in Pakistan adopted a policy of promotion and protection of foreign investments in the country.

\section{Policy Framework in Pakistan for Foreign Investment}

In pursuit of such protectionist approach for foreign investment, Pakistan has undertaken affirmative measures through its three organs: executive actions, legislative actions and judicial conformity to international obligations. Policy 
framework of the country has incorporated vision for promotion and protection of foreign investments in Pakistan. Political regimes in Pakistan have endorsed a policy framework to attract and protect foreign investment in the country. Investment policies of government, indicative of its consistent commitment, attract and facilitate foreign investment in Pakistan. The statutory framework of the country has recognized foreign investors' rights and protection of their interests.

The policy documents of successive governments such as the Five Years Plans, MOUs, and joint declarations with others have been the reflection of affirmative approach to protectionist approach in Pakistan. In 2001, Pakistan and European Community signed an agreement of cooperation for creating favorable conditions for enhancing cooperation in commercial, economic, investment, science and technology, and cultural sectors. One of the principle objects of this agreement was to promote mutual links to build economic capability for investment in Pakistan. The contracting parties take measures to facilitate commercial operations and to establish favorable conditions for transfer of capital to increase mutually beneficial investments (Agreement EC and Pakistan on Partnership and Development, 2001). Pakistan signed another policy framework agreement with USA in 2003 to identify and encourage opportunities for trade and investment (Framework Agreement between USA and Pakistan, 2003).

The framework agreement was an effort to establish bilateral mechanism, attract investment by taking measures, and raise the process of consultation between the two countries. The parties agreed upon to establish a council on trade and investment with the provision to hold regular meetings to monitor trade and investment relation and to work for the removal of impediments for the flow of investment from private sector. Apart from policy framework agreements endorsed by executives, legislative measures have been taken for the facilitation and protection of foreign investments in the country.

\section{Statutory Framework of Pakistan to Foreign Investment}

Parliament has been vested with the legislative authority on the subjects provided in the fourth schedule of the Constitution. The Federal Legislative List enlisted subjects for federal legislature. Legislative organ of the state has incorporated laws and provisions for the implementation of treaties and conventions with the effect to promote and protect foreign investments in the country (Fourth Schedule of the Constitution of Pakistan, 1973).The regulatory framework in Pakistan has adopted facilitative and protectionist approach of foreign investment in the country. Statutory laws for structural reforms, privatization, and denationalization of public owned enterprises were introduced in Pakistan.

One of the significant pieces of legislation after the promulgation of The Constitution was The Foreign Private Investment (Promotion and Protection) Act 1976. This legislation has been an endeavor to pave the ways for the liberalization of Pakistan's economic profile. The Act of 1976 authorized the Federal government to 
allow for the opening of new categories for foreign investment in the country. Foreign investors were allowed to open foreign currency accounts for purchase of any assets for the production, distribution, providing of services, and extraction of mineral resources. Foreign investors were entitled for the repatriation of original investment, its profits, and appreciation of assets at their discretion. The employee or the affiliates of foreign investments transaction could make remittances freely for their dependents. The provisions for concessions in income, wealth taxes, and exemption from double taxation had been introduced, in order to facilitate foreign investors. The Act bounded the state to treat foreign investment with similar treatment which is available for any other investment in Pakistan (FPIA, 1976). This post nationalization legislation has introduced provisions to ensure facilitative provisions for foreign investors to participate for designated areas of business.

The Protection of Economic Reforms Act 1992 was promulgated to introduce fiscal incentives to foreign investors and deregulation of their investments in the country (PERA, 1992). Foreign investors have been encouraged to bring inflow of foreign capital or repatriation of assets with minimum restrictions and accountability through simplest possible procedural requirements. The Act 1992 has created for the foreign investors a freedom to open foreign currency account without declaring the source of money. These foreign currency accounts were protected with assurance of a compulsory maintenance of secrecy by banks. Furthermore, foreign investment accounts were immune from any Tax deductions including wealth, income taxes, and zakat. Foreign investment made for purchase of privatized enterprise could not be taken over or acquired by the government for any reason (PERA, 1992).

Ten years later, the Special Economic Zones Act, 2012 was introduced for the purpose to establish geographically defined special economic zones, territories, outside jurisdiction of customs for imposing tariff on the products. To seek collaboration of private investors and developers, tax exemptions are introduced for their machineries and products. The High Courts of the respective province has jurisdiction to resolve any disputes of civil nature if arise with the local authorities (SEZs Act, 2012). These elevated provisions have been introduced to build confidence and dependability on a patent system of dispute resolution in Pakistan.

The Board of Investment (BOI) Ordinance 2001 was promulgated to provide one window operations to facilitate foreign investors for their investment transactions. The data on investment is maintained and liaison with private sector for their active participation (BIO, 2001)). Board is responsible to identify investment opportunities and initiate investment categories with the assistance of provincial board of investments. BOI has been authorized to review investment projects and submit recommendations of special incentives or relaxations to the Cabinet Committee on Investment (CCOI). Board has to coordinate with relevant ministries, agencies, and department for the formulation of investment policies to ensure transparency. The administrative, financial, and management decisions affecting 
foreign investments were communicated to foreign private investors to keep them informed (BIO, 2001).

\section{Pakistan's Affirmative Approach for Transnational Protectionism}

Pakistan Participated in the global efforts to promote and protect foreign investment. These efforts have been undertaken with the vision to facilitate flow of foreign investment across nations. The multilateral investment treaties, regional agreements, free trade agreement and bilateral investment with more than 50 other countries in recent decades have been established to pursue an affirmative policy for free trade and protection of foreign investment. Pakistan signed two agreements for the promotion and protection of investments among Organization of the Islamic Conference (OIC) and Economic Cooperation Organization (ECO). In case of investment dispute, both of these comprehensive multilateral agreements provided investment protection provisions along with dispute settlement procedures for investors. Both agreements undertook to provide a desirable framework of foreign investment protection. These agreements have incorporated dispute resolution mechanism for investment disputes.

In 1986, The Agreement on Promotion, Protection and Grantee of Investments among Members State of the Organization of the Islamic Conference (OIC) were committed to develop a climate for investment for optimum utilization of resources of the member countries. The members undertook commitment to provide necessary facilities for entry, residence, working, and exit of private investor through this multilateral agreement. The members agreed to refrain from adopting any measures which may deprive the investor from utilization and management of investment. Article 17 of the agreement provided dispute settlement mechanism for investment disputes on the request of either foreign investor from OIC countries or the host member state. The parties of investment agreement would have the option to file request with the Secretary General of OIC either for reconciliation or arbitration mechanism. The decision of arbitration tribunal shall be final and shall have the effect of judicial decisions of the host state (Agreement on Promotion, Protection and Grantee OIC, 1986).

Another regional agreement for the promotion and protection of foreign investment was signed by the state in 2005 (yet not enforceable), the members of Economic Cooperation Agreement (ECO). The multilateral agreement concluded for promotion and protection of investment among ECO members' states. Members undertook to build a favorable climate for the investment by setting up minimum standards of its promotion and protection. The agreement incorporated provisions for admissions, entry, residence, treatment standards, and repatriation of every kind of assets. The disputes settlement mechanism clauses in case of expropriation or nationalization of foreign investments provided for prompt, adequate, and effective compensations. Agreement provided with two options or otherwise agreed by the parties through their respective investment contract: the investor is entitled to file dispute with the domestic courts of the host state or to opt for ad hoc arbitration 
under UNCITRAL rules of arbitration. The domestic court or ad hoc tribunal has no jurisdiction to interfere each other's proceedings during pendency of the litigation before the arbitral tribunal, constituted under the agreement. At the same time, the disputing parties can invoke any other jurisdiction under investment treaty including free trade agreements or bilateral investment treaties (BIT) (Agreement on promotion and protection ECO member, 2005). The rhetoric of foreign investment protection is being secured by dispute settlement mechanism as an essential clause of the investment treaties.

The free trade agreements (FTA) of Pakistan have referred its provisions for the protection of foreign investments of the contracting states. South Asian Regional Free Trade Agreement has incorporated provisions for the promotion of investment among the member nations. The agreement was originally to establish a free trading regime among the SAARC countries with the object of preferential trading arrangements. The contracting parties have concluded to take measures for the removal of barriers to intra-SAARC investments. The agreement does not provide dispute settlement mechanism for the investment dispute, but for trade dispute (SAFTA, 2006). On the other hand, FTAs with China and Malaysia specifically referred to protectionist approach for foreign investment in Pakistan. Investment treaties, including FTA, have incorporated Investor State Dispute Settlement (ISDS) mechanism to ensure the protection of foreign investment.

China-Pakistan FTA, 2006 has introduced two options for the ISDS to protect the international obligations of the host state: foreign investors are required to approach administrative agencies of the host states before opting for litigations. In case the investment dispute remained unresolved even after the expiry of six months of the notice of dispute, the complainant investor has the option to file its dispute with the domestic courts or to invoke ICSID jurisdiction. The provision of the treaty has ensured any choice, which shall be final. In case foreign investor chooses to file its litigations with domestic courts, the complainants are barred to invoke ICSID jurisdiction for the same dispute. The consequent award announced for the dispute from either forum shall be final and binding for the parties (China-Pakistan FTA, 2006). FTA has restricted to invoke parallel litigation on multiple forums. On the other hand, Malaysia-Pakistan FTA, 2007 provided with the three options for the investors to choose for its disputes resolution mechanism: Article 98 of the Malaysia Pakistan FTA provides three options for the international arbitration mechanism: the investor can choose to file its investment dispute before Kuala Lumpur Regional Centre for Arbitration or ad hoc arbitration under UNCITRAL rules of arbitration or to invoke ICSID jurisdiction. The investor and host state can be agreed for any rules of arbitration or forum through their investment contracts. Investor has the option to file dispute with the domestic administrative or judicial forums of the host state. Article 98 has barred foreign investors to approach any international arbitration procedure if the case has already submitted before the domestic forums. The FTA has introduced two rare provisions in the agreement regarding the limitation for filing of the claim and restitution as another choice of remedy for the tribunals other than damages (Malaysia Pakistan FTA, 2007). The FTA provides that the investor 
whose investment is violative of the laws and policies of the host state shall not be entitled to redress their claim by availing these options.

FTAs have introduced additional procedures for the settlement of investment disputes for the investor in presence of Bilateral Investment Treaty (BIT) between the two states. The consolidated effect of FTA and BIT is that foreign investors from contracting states have choices to resolve their investment disputes by availing either procedures under BIT or FTA. The rising trend of BITs became major contributory factor for the protection of foreign investment in the world. The nations of the world have executed a stock of 2901 BITs with 2342 enforceable instruments (investment policy.unctad.org). BIT as a crucial instrument underwriting economic globalization by providing wide range of investment protections (Waibel \& Wu, 2017). BITs are written agreements between the states which are governed by international law to regulate the rights relating to foreign investments in host states (Art. 2(1) (a), VCLT, 1969). These agreements have been created to protect the beneficial interests of the foreign investors and their investments in some foreign territory

Susan D. Frank (2004) has identified two contributory factors for the proliferation of investment treaties: the incorporation of substantive rights and direct access to remedies for foreign investors in violation of these substantive obligations of the investment treaty. The LDCs signed these BITs to collect more benefits from open market economic patterns of the world rather than commitment for their legal obligations. These countries adopted these binding agreements to attract investments for the economic self-interests. The countries which sign BITs protection have been able to secure more foreign investment than those not adopted this system of investor protection. This contracting regime protection system proved to be the incentive for foreign investors to invest and for LDCs to promote well-being in those states (Guzman, 1997).

First ever BIT was signed between Pakistan and Germany in 1959. Pakistan actively supported development of bilateral investment treaties up till the year 2000 and preferred to select transnational national forum of foreign dispute resolution. Pakistan signed 53 BITs until November 2020 with 48 nations including lessdeveloping, developing, and developed economies of the world (investmentpolicy.unctad.org). The end of Cold War and the emergence of unipolar economic regime in the world in the last decade of $20^{\text {th }}$ century has been the defining moment for new economic order in the world. Pakistan signed its 32 bilateral investment treaties in such era of proliferation of BITs to attract foreign capital to gear up the growth of economy.

The structures of bilateral investment treaties in Pakistan have articulated its provisions for admission of foreign investment, standard of treatment with investment, and repatriation of assets of foreign investors of contracting states. The dispute resolution clauses included substantive rights to compensate in case of expropriation and procedural right to directly bring its claim before supranational arbitral tribunals (Ghouri, 2011). BITs are offering disputes resolution forums for the 
investors of contracting states. The disputes resolution clauses of BITs provide three possible options for settlement of investment disputes. These include domestic arbitration forums, ad hoc arbitration tribunal, and transnational institutional arbitrations forums. Institutional arbitration is being conducted under the aegis of an arbitration institution. The important international forums of institutional arbitration include International Centre for the settlement of investment disputes (ICSID), International Court of arbitration of International Chamber of Commerce (ICC), London Court of International Arbitration (LCIA), the Arbitration Institution of Stockholm Chamber of Commerce (SCC), and other regional arbitration centers, which had been set up in Asia, Middle East, Africa, and North America.

Pakistan has been part of multilateral investment agreements, free trade agreement, and investment treaties. Participation for a comprehensive international framework for flow of foreign investment and its protection has encouraged state to accept an impartial and independent mechanism for investment dispute resolution. Pakistan has acknowledged ICSID jurisdiction in most of the investment treaties and agreements for ISDS.

The capital exporting nations and their investors prefer to submit their claims in case of disputes to these institutional tribunals at some neutral place before impartial judges rather than domestic court (Review Association, 1995-2012). These tribunals are considered depoliticized (Shihata, 1995) and beyond dominant influence of host country's authorities (Al-Saeed, 2002). Other reasons for adopting this institutional arbitration approach for the settlement of foreign investment disputes are risk of abuse of legal procedure and transparency under local procedural laws. The domestic laws and procedure are evaluated as below minimum standard of justice and equity (QC, S. P. S., 2008). The inconsistent government policies and commitments, along with instances of expropriations without adequate compensations can be cited as justification for the transnational arbitrations (Al-Saeed, 2002). The trend of supranational institutional arbitration for ISDS was on the rise since 1979 and increasingly providing a substitution for the domestic litigation for the purpose (Brower \& Sharpe, 2003). The perceived partiality of host state court system is another factor for shift of paradigm from national to transnational adjudications. The reluctance and handicaps of domestic courts to scrutinize fully the affair of a sovereign state action for constitutional or legal reasons of act of the state in its sovereign capacity has justify to redress the disputes in some international forums by independent adjudicators (Brower \& Schill, 2008).

\section{ICSID Jurisdiction in Pakistan}

Pakistan signed ICSID Convention on $6^{\text {th }}$ July, 1965 and deposited its ratification on $15^{\text {th }}$ September, 1966. The ICSID Convention came into force after 30 days, i.e. 15 $5^{\text {th }}$ October, 1966 (icsid.worldbank.org). Pakistan has acknowledged the Convention by incorporation procedure of enforcement of award in the national legal framework through enactment of The Arbitration (International Investment Disputes) Act, 2011. The enactment has made it mandatory through the High Court 
to enforce award announced by the ICSID tribunal. The pecuniary obligations under the award are executable like judgment of High Courts (Arbitration Act, 2011). The legislation has been reassurance of the state to protect investment interests of foreign investors.

The first ICSID litigation was filed against Pakistan in 1987 for the mining dispute by an American multinational corporation (Occidental v. Pakistan, 1987). Till November, 2020, out of eight complaints, two claims were withdrawn before the constitution of arbitration tribunals. The Secretary General of ICSID constituted the arbitration tribunals in the six claims against Pakistan, i.e. Impregil, 2002 and Occidental v. Pakistan, 1987). Three claims ended up in pro-investor compromises (Impreglio, 2003, Bayindir, 2003, SGS, 2001). In all these investment disputes, Pakistan, as respondent, challenged ICSID jurisdiction. ICSID tribunals rejected such objections to assume its jurisdiction (icsid.worldbank.org).

The three out of six claims ended up in pro investor compromises with foreign investors and host state before pronouncement of final award (Bayindir, 2003, SGS, 2001, Impreglio, 2003). The ICSID tribunals rendered final awards in three investor state investment disputes (ISDS) (Agility, 2011, Tethyan, 2012, \& Karkey v. Pakistan, 2013). In case of Agility Corporation, the Tribunal rejected the claim of foreign investor. In two litigations i.e. Tethyan Copper Co. and Karkey ICSID tribunals have pronounced award of damages against Pakistan when the Supreme Court of Pakistan declared both the contract void ab initio. These cases engendered jurisdictional conflict between ICSID tribunal and the Supreme Court of Pakistan. Both of these jurisdictional controversies finally ended up with pronouncement of billion dollars awards, which are a serious blow to the fragile economic conditions of Pakistan (Tethyan 2012, Karkey v. Pakistan, 2013).

\section{Evaluation of Protectionist Approach in Pakistan}

Pakistan undertook efforts to promote foreign direct investment from capital exporting nations of the world. The framework agreement with the USA and cooperation agreement with European Community provide investment related provisions, but not providing any procedure for dispute resolution. The US-Pak framework agreement has been considered an effort in the backdrop of an ally in war against terrorism, to approach US capital market and to attract foreign investments.

The statutory framework of Pakistan has introduced facilitative environment for protection of foreign investment in the country. Protection is provided for original capital, its profits, and related interests of investment transaction. The statutory provisions of laws provide an assurance to protect interests of foreign investors through its settlement of investment disputes procedures. The Act of 1976 provided that in case the Federal government is required to take over the undertaking of foreign investment, it is mandatory for the Federal government to adopt a due process of law. The Federal government is bound by law to pay an 
adequate compensation to investor in the currency of the origin of investment (FPIA, 1976). Board of Investment has been authorized to negotiate and finalize international bilateral or multilateral agreement on investment. The Board is responsible to negotiate for the dispute settlements with foreign investors and monitor such mechanism for the protection of investment in Pakistan (BIO, 2001). Pakistan signs forty-one out of fifty-three BITs before the establishment of BOI to owe international obligations for the resolution of foreign investment disputes (investmentpolicy.unctad.org).

In 1990s, with the collapse of cold war, proliferation of BITs attributed for some major factors. These factors include the abandonment of controlled economy. The factor of controlled economy discouraged when the regime of official assistance withheld after the collapse of USSR after a long cold war with the USA. This generated a demand of foreign money to fulfill the needs or to run the affairs of the states. This demand of foreign money shifts the priorities of states. The states shifted their economic policies from dependent to free market economy. The nonavailability of financial assistance from the major players of cold war was the main reason for the emergence of free competition to attract foreign money and new technology for further job creation and social development. This dire need of the capital dragged capital importing countries on low profile in bargaining for the commitment for protection of existing and future interests of foreign investors (Kaushal, 2009).

BITs being sovereign decree are treated to have overriding effect over constitutional and domestic laws of the contracting state. BIT instrumentalities have created contractual liabilities of sovereign states in favour of third party even have no privy to the agreement (Ghouri, 2011). The BITs have created obligations for the host states without having any enforceable right against foreign investors (Gazzini, 2012). Foreign investors, despite stranger to the contracts, are preferred beneficiaries through their substantive and procedural right to access the ISDS jurisdictions without the interference of the contracting parties.

ICSID provides a flexible approach to access its jurisdiction even without any interference of the home state (Art 25 of the ICSID Convention, 1965). The doctrine of sovereign immunity and act of state are inapplicable to resist private enforcement of international obligations (Garcia, 2004). In ICSID arbitration, jurisdiction can be invoked by foreign investor only wherein host state is to be permanent respondent. Host state has no right to claim the violations of foreign investment agreement by the investors (Art 25 of the ICSID Convention, 1965). Thus, host state cannot invoke jurisdiction against foreign investors. Foreign investor has become one of the actors at par with the status of states in international law (Garcia, 2004). Foreign investor under the contemporary regime of investment protection has been elevated with preferential right to claim against host states and have no obligations for which they can be held liable (Gazzini, 2012). Damages are the only remedy available against host state without exhausting any prior requirements (Van Harten, G., 2010). At the 
same time there is no hard and fast rule to follow the source of law to assess the damages of award.

The contracting parties cannot frustrate investment treaty unilaterally after its ratification. The dispute settlement clause shall have the binding effect till the expiry of the investment treaty. Pakistan has thirty-three enforceable out of fiftythree bilateral investment treaties with developing and developed economies of the world. The majority of these treaties have referred ICSID jurisdiction for foreign investors from contracting parties. Bilateral and multilateral investment treaties have created standing offer of dispute mechanism for foreign investors till the expiry of investment treaty. This standing can be accepted by foreign investor by sending letter of acceptance to Secretary General ICSID at the time of filing litigation with ICSID jurisdiction (Toral \& Schultz, 2010). As a matter of fact, consent of contracting sovereign states has been prospectively available against the host state even without the intervention of contracting state. (Harten, 2010). The vulnerability apparent from the unequal status of foreign investor and pattern of decisions by ICSID tribunals under the contemporary regime of investment protection wherein multinational corporations dominantly win in majority of cases of investment disputes against host state. At the same time, majority of ICSID litigations resulted in granting heavy damages against the respondents (Nolan, 2015).

\section{Conclusions}

The successive government in Pakistan facilitated and protected foreign investments. State organs have endorsed policy of foreign investment. The Constitution provides subjects to legislate laws for the protection of foreign investment in the country. Parliament has passed Foreign Investment (Promotion and Protection) Act 1976, which opened up new categories for the sake of attracting foreign investment in post nationalization era. Foreign currency accounts have been incentivized under the authority of the Act. Concessions and exemptions are available on the invested assets and its profits even in case of repatriation of foreign investment from Pakistan. Furthermore, The Protection of Economic Reforms Act, 1992 provides to maintain secrecy of foreign investment capital. To strengthen coordinated measures for the attraction and protection of interests of foreign investors, Board of Investment Act 2001 has been authorized to establish linkage among different departments of the government. The Board is responsible to finalize investment instruments and communicate decisions to foreign investors.

Apart from statutory support to facilitate foreign investment, executive in Pakistan has played its decisive role to acquire pro-investors policy measures. Legal framework agreements with the USA and European Community have been undertaken to enhance economic opportunities and capabilities for foreign investors. Executives have finalized more than fifty investment treaties including FTAs and BITs. These investment agreements have undertaken assurances to protect foreign investment for the investors of contracting states. Multilateral or bilateral assurances have been guaranteed by incorporating provisions of dispute settlement in case of 
dispute with the host state. The perceived impartial and independent transnational arbitration mechanisms have been referred in thirty-three enforceable bilateral investment treaties in Pakistan. Majority of these investment treaties have consented to ICSID jurisdiction.

Thus, contracting states are denied access to deal with disputes bilaterally or multilaterally after the acceptance of standing consent to accept ICSID jurisdiction. Obligations under ICSID have engendered surrendering effect for exploiting natural resources, internal economic policies, and to regulate public rights. ICSID obligations in Pakistan have its impact to restrict the authority to make laws and to take policy decisions to regulate domestic issues of public nature. Consequently, investment treaty obligations have undermined sovereign authority to decisions even upon national interest in Pakistan.

Pakistan ratified ICSID jurisdiction in the first year of its enforcement in 1966. Pakistan Romania BIT of 1978 was the first to consent for ICSID arbitration mechanism for investor-state settlement of foreign investment disputes. The first of total eight filing against Pakistan appeared in Occidental v. Pakistan in 1987. Impregilo v. Pakistan was withdrawn before the constitution of ICSID tribunal and re-filed later in 2003. Three ICSID litigations were ended up with pro-investors compromise to avoid hefty awards of damages of millions of dollars. Rest of three ICSID contested claims against Pakistan were decided for final awards. In the contested cases of Tethyan Copper v. Pakistan and Karkey Electric v. Pakistan, the host state received the awards of $\$ 5$ billion and $\$ 1.6$ billion dollars. By virtue of the Arbitration (Promotion and Protection) Act 2012, these awards of ICSID tribunal are binding upon government of Pakistan and enforceable like final decree of the domestic courts. ICSID awards are enforceable against any assets of Pakistan in any foreign territory.

These hefty awards have created economic challenges in the backdrop of fragile economic conditions in Pakistan. Thus, taking into account pro-investor protectionist approach of Pakistan, the paper suggests reevaluation of international obligations in investment treaty, in order to devise a rational approach by creating balance between interests of investors and the host state. Skilled negotiations and effective parliamentary supervision for international instruments can help avoid economic vulnerabilities in future. 


\section{References}

Agility for Public Warehousing Company K.S.C. v. Islamic Republic of Pakistan (ICSID Case No. ARB/11/8)

Agreement on South Asian Free Trade Agreement 2006 is agreement among the member of SAARC (South Asian Association for Regional Cooperation) organization established in 1993 in Dhaka by its contracting member, i.e., Bangladesh, Bhutan, India, Maldives, Nepal, Pakistan and Sri Lanka

Al-Saeed, M. (2002). Legal protection of economic development agreements. Arab Law Quarterly, 17(2), 150-176.

Bayindir Insaat Turizm Ticaret Ve Sanayi A.S. v. Islamic Republic of Pakistan (ICSID Case No. ARB/03/29)

Board of Investment Ordinance 2001

Brower, C. N., Brower, C. H., \& Sharpe, J. K. (2003). The coming crisis in the global adjudication system. Arbitration International, 19(4), 415-440.

Brower, C. N., \& Schill, S. W. (2008). Is arbitration a threat or a boom to the legitimacy of international investment law. Chi. J. Int'l L., 9, 471.

China-Pakistan Free Trade Agreement, 2006

Franck, S. D. (2004). The Legitimacy Crisis in Investment Treaty Arbitration: Privatizing Public International Law through Inconsistent Decisions. Fordham L. Rev., 73, 1521.

Guzman, A. T. (1997). Why LDCs sign treaties that hurt them: Explaining the popularity of bilateral investment treaties. Va. j. Int'l L., 38, 639 .

Garcia, C. G. (2004). All the other dirty little secrets: Investment treaties, Latin America, and the necessary evil of investor-state arbitration. Fla. J. Int'l L., 16, 301.

Ghouri, A. A. (2011). Positing for balancing: investment treaty rights and the rights of citizens. Contemp. Asia Arb. J., 4, 95.

Gazzini, T. (2012). Bilateral investment treaties. In International Investment Law (pp. 99-132). Brill Nijhoff.

Harvard Law Review Association. Protection of Foreign Direct Investment in a New World Order: Vietnam. A Case Study. Harvard Law Review, 107, 1995-2012.

https://icsid.worldbank.org/en/Pages/about/Database-of-Member-States 
https://investmentpolicy.unctad.org/

ICSID Convention, 1965.

Impregilo S.p.A. v. Islamic Republic of Pakistan (ICSID Case No. ARB/02/2)

Impregilo S.p.A. v. Islamic Republic of Pakistan (ICSID Case No. ARB/03/3)

Karkey Karadeniz Elektrik Uretim A.S. v. Islamic Republic of Pakistan (ICSID Case No. ARB/13/1)

Kaushal, A. (2009). Revisiting history: how the past matters for the present backlash against the foreign investment regime. Harv. Int'l LJ, 50, 491.

Malaysia Pakistan Free Trade Agreement, 2007

Nolan, M. (2015). Challenges to the credibility of the investor-state arbitration system. Am. U. Bus. L. Rev., 5, 429

Occidental of Pakistan, Inc. v. Islamic Republic of Pakistan (ICSID Case No. $\mathrm{ARB} / 87 / 4)$

Organization of the Islamic Conference, 1986

QC, S. P. S. (2008). International investment law: reconciling policy and principle. Hart Publishing

SGS Société Générale de Surveillance S.A. v. Islamic Republic of Pakistan (ICSID Case No. ARB/01/13)

Shihata, I. F. (Ed.). (1995). The World Bank in a Changing World: Selected Essays and Lectures (Vol. 2). Martinus Nijhoff Publishers. Mansour Al-Saeed, "Legal protection of economic development agreements," Arab LQ 17(2002): 150-176.

South Asia Free Trade Agreement, 2006

The Constitution of Islamic Republic of Pakistan, 1973.

The Foreign Private Investment (Promotion and Protection) Act 1976.

The Agreement on Promotion, Protection and Grantee of Investments among Members State of the Organization of the Islamic Conference 1986.

The Protection of Economic Reforms Act 1992.

The Cooperation Agreement between the European Community and The Islamic Republic of Pakistan On Partnership and Development 2001. 
The agreement on promotion and protection of investments among ECO member states 2005.

The Arbitration (International Investment Disputes) Act, 2011

Tethyan Copper Company Pty Limited v. Islamic Republic of Pakistan (ICSID Case No. ARB/12/1)

Toral, M., \& Schultz, T. (2010). The state, a perpetual respondent in investment arbitration? Some unorthodox considerations. The Backlash Against Investment Arbitration: Perceptions and Reality, 577-602.

The Special Economic Zones Act, 2012.

USA-Pak framework agreement, 2003

Van Harten, G. (2010). Investment treaty arbitration, procedural fairness, and the rule of law. International Investment Law and Comparative Public Law.

Vienna Convention on Law of Treaties

Waibel, M., \& Wu, Y. (2017). Are Arbitrators Political? Evidence from International Investment Arbitration. Working Paper. http://wwwbcf. usc. edu/ yanhuiwu/arbitrator. National Interest. 